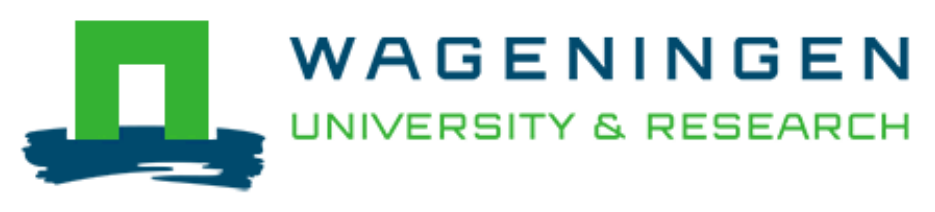

Evaluating dietary supply of microminerals as a premix in a complete plant ingredient-based diet to juvenile rainbow trout (Oncorhynchus mykiss)

Prabhu, P. A. J., Schrama, J. W., Fontagné-Dicharry, S., Mariojouls, C., Surget, A., Bueno de Mesquita, M., ... Kaushik, S. J.

This article is made publically available in the institutional repository of Wageningen University and Research, under article 25fa of the Dutch Copyright Act, also known as the Amendment Taverne.

Article $25 \mathrm{fa}$ states that the author of a short scientific work funded either wholly or partially by Dutch public funds is entitled to make that work publicly available for no consideration following a reasonable period of time after the work was first published, provided that clear reference is made to the source of the first publication of the work.

For questions regarding the public availability of this article, please contact openscience.library@wur.nl.

Please cite this publication as follows:

Prabhu, P. A. J., Schrama, J. W., Fontagné-Dicharry, S., Mariojouls, C., Surget, A., Bueno de Mesquita, M., ... Kaushik, S. J. (2018). Evaluating dietary supply of microminerals as a premix in a complete plant ingredient-based diet to juvenile rainbow trout (Oncorhynchus mykiss). Aquaculture Nutrition, 24(1), 539-547. https://doi.org/10.1111/anu.12586 


\title{
Evaluating dietary supply of microminerals as a premix in a complete plant ingredient-based diet to juvenile rainbow trout (Oncorhynchus mykiss)
}

\author{
P. Antony Jesu Prabhu
$1,2,3$ (i) $\mid$ J.W. Schrama \\ A. Surget $^{1} \mid$ M. Bueno ${ }^{4}$ | I. Geurden ${ }^{1}$ | S.J. Kaushik ${ }^{1}$
}

${ }^{1}$ INRA, UR 1067, NuMeA, Aquapôle, SaintPée-sur-Nivelle, France

${ }^{2} \mathrm{AFI}$, WIAS, Wageningen University, Wageningen, The Netherlands

${ }^{3}$ AgroParisTech, Paris Cedex 5, France

${ }^{4} \mathrm{CNRS} /$ Université of Pau \& Pays de l'Adour, Institut des Sciences Analytiques et de Physico-Chimie pour l'Environnement et les Matériaux, LCABIE, UMR 5254, 64053 Pau, France

\section{Correspondence}

Sadasivam J. Kaushik, INRA, UR 1067, Nutrition, Metabolism and Aquaculture (NuMeA), Aquapôle, Saint-Pee-sur-Nivelle, France.

Email: sadasivam.kaushik@inra.fr

Present Address

P. Antony Jesu Prabhu, National Institute of Nutrition and Seafood Research (NIFES), PO Box 2029 Nordnes, 5817 Bergen, Norway

\section{Funding information}

Institut National de la Recherche

Agronomique; ARRAINA: Advanced Research Initiatives for Nutrition \& Aquaculture, Grant/ Award Number: KBBE-2011-288925

\begin{abstract}
Two basal diets $\mathrm{MO}$ and $\mathrm{V} O$ were formulated with marine and plant based ingredient composition. Seven experimental diets were prepared from the two basal diets namely $\mathrm{MO}, \mathrm{M100}$, V0, V30, V60, V100 and V150 by incorporating different levels of a micromineral premix ( $\mathrm{Cu}, \mathrm{Fe}, \mathrm{Mn}, \mathrm{Se}$ and $\mathrm{Zn}$ ). Triplicate groups of rainbow trout (initial weight: $20 \mathrm{~g}$ ) reared at $17^{\circ} \mathrm{C}$ were fed one of each diet to apparent visual satiation over 12 weeks. Among the $\vee$ diet fed fish, growth and feed intake exhibited maximal response at $\mathrm{V} 60$ level of premix inclusion; Apparent availability coefficient of $\mathrm{Fe}, \mathrm{Cu}$ and Zn decreased linearly with increasing level of premix whereas apparent availability coefficient of $\mathrm{Mn}$ and Se was unaffected. The available dietary concentration in basal $\mathrm{VO}$ diet was for Fe, 20.6; Cu, 2.8; Mn, 6.5; Zn, 17.3 and Se, 0.195 (in mg/kg DM) and in the M0 diet for Fe, 63.3; Cu, 5.2; Mn, 2.9; Zn, 35.2 and Se, 0.87 (in mg/kg DM). In reference to NRC (Nutrient requirements of fish and shrimp. Washington, DC: National Research Council, The National Academies Press, 2011) recommendations, the Vo basal diet accounted for $34.3 \%, 92.9 \%, 53.9 \%, 115 \%$ and $130.2 \%$ and the contribution from MO diet for $105.5 \%, 173.3 \%, 24.2 \%, 234.7 \%$ and $580 \%$ of the minimal dietary inclusion levels of $\mathrm{Fe}, \mathrm{Cu}, \mathrm{Mn}, \mathrm{Zn}$ and Se to rainbow trout, respectively. However, data on whole body mineral contents showed that normal levels were maintained only for $\mathrm{Cu}$ and $\mathrm{Mn}$ through supply from basal V0 diet. For Zn and Se, available supply even from the highest supplemented diet (V150) was not sufficient to maintain normal body mineral levels of rainbow trout in the present study. On the whole, optimal dietary inclusion levels of microminerals are altered while using fishmeal-free diets for rainbow trout.
\end{abstract}

\section{KEYWORDS}

fishmeal replacement, micro minerals, premix, rainbow trout, requirement, supplement, trace minerals

\section{1 | INTRODUCTION}

Mineral requirements of fish and optimal dietary inclusion level in particular of micro minerals such as $\mathrm{Fe}, \mathrm{Cu}, \mathrm{Mn}, \mathrm{Zn}$ and $\mathrm{Se}$ in fish feeds are not well understood (Lall, 2008). As regards rainbow trout, estimates on requirements for all micro minerals, except for iron (Fe), are available (NRC, 2011). The recommendations of National Research Council (NRC) are based on "requirement estimates determined with highly purified ingredients in which the nutrients are highly digestible and therefore the values represent near 100\% bioavailability." 
Under practical conditions, the dietary inclusion level of micro minerals needed to meet the requirement can vary based on a number of physiological and environmental factors (Hilton, 1989; Sugiura, Dong, $\&$ Hardy, 2000). The ingredient composition of practical fish feeds is one such factor (Watanabe, Kiron, \& Satoh, 1997). The latter authors found that micro minerals such as $\mathrm{Fe}, \mathrm{Cu}, \mathrm{Mn}$, Se and $\mathrm{Zn}$ are important to be supplemented in fish feeds due to the low levels in practical feed ingredients and interactions with other dietary components. The magnitude of supplementation depends on the intrinsic contribution from the basal ingredients and interactions affecting the availability of the micro minerals. Over the years, the use of marine ingredients such as fishmeal and fish oil in fish feeds has seen a significant reduction, and they are replaced to a large extent by plant-derived protein and lipid sources (Tacon \& Metian, 2008). Fishmeal is generally rich in micro minerals (Julshamn, Haugsnes, \& Utne, 1978), but appreciable levels of certain micro minerals are also found in plant-derived ingredients, at times even many folds higher than in fishmeal, as seen for the Mn content of white lupin (NRC, 2011). Considering the supply of micro minerals from the different ingredients themselves (Lall, 2008; Sugiura, Dong, Rathbone, \& Hardy, 1998), it is necessary to evaluate the need for and level of supplementing one or more micro minerals to plant ingredient-based diets which are completely devoid of fishmeal. Based on the foresaid considerations, a study with juvenile rainbow trout was undertaken to evaluate the NRC (2011) recommendations for micro minerals and determine the optimal range of micro mineral supplementation required to a complete plant ingredient-based diet.

\section{MATERIALS AND METHODS}

\section{1 | Experimental diets}

Two basal diets ( $\mathrm{MO}$ and $\mathrm{V} 0$ ) were formulated with the basal ingredient composition provided in Table 1. The diets were made either with fishmeal as the major protein source (M) or entirely of plant-derived ingredients $(\mathrm{V})$ and supplemented with di-calcium phosphate to meet the available phosphorus requirement of rainbow trout (Antony Jesu Prabhu et al., 2014; NRC 2011). A micromineral (Fe, Cu, Mn, Zn and $\mathrm{Se}$ ) premixture was designed to meet the theoretical requirements of rainbow trout (NRC, 2011) at an inclusion level of $10 \mathrm{~g} / \mathrm{kg}$ diet contributing Fe, 52.5 mg; Cu, 7.5 mg; Mn, 12 mg; Zn, 14 mg; and Se, $0.15 \mathrm{mg} / \mathrm{kg}$ diet, on as fed basis. This premix was included at incremental levels of $0,3,6,10$ and $15 \mathrm{~g} / \mathrm{kg}$ diet to the basal $V$ diet to provide diets $\mathrm{V} 0, \mathrm{~V} 30, \mathrm{~V} 60, \mathrm{~V} 100$ and $\mathrm{V} 150$, respectively, whereas, in the $M$ diet, the premix was included at 0 and $10 \mathrm{~g} / \mathrm{kg}$ diet to give $\mathrm{MO}$ and $\mathrm{M} 100$, respectively. For the measurement of the apparent availability of minerals, the diets were prepared with the incorporation of $0.1 \mathrm{~g} / \mathrm{kg}$ yttrium oxide $\left(\mathrm{Y}_{2} \mathrm{O}_{3}\right)$ as the inert marker.

\section{2 | Fish, feeding and rearing condition}

Rainbow trout juveniles $(19.8 \pm 0.8 \mathrm{~g}$, IBW) were randomly distributed into 21 experimental units, each of $500 \mathrm{~L}$ (40 fish/unit). Triplicate groups of fish were hand fed twice a day to apparent visual satiation for a period of 12 weeks ( 6 days a week). The fish were reared in flow-through systems at the INRA experimental fish farm at Donzacq (Landes, France). Water temperature was $17 \pm 0.5^{\circ} \mathrm{C}$, and the flow rate of water was maintained at $50 \mathrm{~L} /$ min during the experimental period. The analysed concentrations of minerals in the rearing water (mg/L) were $\mathrm{P},<0.2 ; \mathrm{Ca}, 41.7 \pm 6.3 ; \mathrm{Mg}, 19.2 \pm 0.8 ; \mathrm{K}, 1.8 \pm 0.1 ; \mathrm{Fe}$, $<0.02 ; \mathrm{Mn},<0.02$; $\mathrm{Cu},<0.008, \mathrm{Zn},<0.007$; and Se, 0.002 .

\section{3 | Fish, tissue and faecal sampling}

Fish samples for initial body composition analysis $(n=20)$ were collected at the start of the experiment. Fish from each experimental unit were bulk weighed at the start, every 3 weeks and at the end of the 12 -week growth trial. Feed was withheld for $24 \mathrm{hr}$ before every weighing. At the end of the growth trial and $24 \mathrm{hr}$ after the last meal, six fish were randomly selected from each experimental unit and pooled for final body composition analysis. Out of the remaining fish, 25 fish per tank were used for the determination of apparent availability coefficient (AAC) of minerals. The fish were fed a single meal ( $86 \mathrm{~g} / \mathrm{tank})$, and $9 \mathrm{hr}$ after the meal, faecal samples were collected by the method of stripping (Antony Jesu Prabhu et al., 2014). The samples were collected over ice, frozen immediately and stored at $-20^{\circ} \mathrm{C}$ until mineral analysis. Animal experiments and sampling procedures followed the guidelines of the National Legislation on Animal Care of the French Ministry of Research (Decree no. 2001-464, May 29, 2001) and the animal ethics committee of INRA (INRA 2002-36, April 14, 2002).

\subsection{Analytical methods}

Moisture content of the pooled fish samples was determined by drying freshly ground samples at $105^{\circ} \mathrm{C}$ for $24 \mathrm{hr}$. The chemical composition of the diets and of fish samples were analysed by the following methods: dry matter after drying at $105^{\circ} \mathrm{C}$ for $24 \mathrm{hr}$, ash by combustion at $600^{\circ} \mathrm{C}$ for four hours in a muffle furnace, crude protein ( $\mathrm{N} \times 6.25)$ by Kjeldahl method in acid digested samples, crude lipid by petroleum ether extraction using Soxhlet method (Soxtherm) and gross energy content in an adiabatic bomb calorimeter (IKA, Heitersheim Gribheimer, Germany). The concentrations of P, Ca, Mg, $\mathrm{K}, \mathrm{Fe}, \mathrm{Cu}$ and $\mathrm{Zn}$ in the diets, whole fish and faeces were analysed using inductively coupled plasma-mass spectrometry (ICP-OES) at USRAVE-INRA, Bordeaux, France. The Se and yttrium content in the samples were analysed using ICP-MS at LCABIE-UPPA, Pau, France. The analysed chemical composition and macro-mineral concentration of the basal $\mathrm{VO}$ and $\mathrm{MO}$ diets are presented in Table 1, and the micromineral concentration of the diets are provided in Table 2.

\section{5 | Data analysis}

Tanks ( $n=3$ ) were used as experimental units for data on growth, body composition and mineral balance. All data were subjected to one-way ANOVA followed by Tukey's multiple comparison test at a probability of $p<.05$. All the data analysis was performed using SPSS version 20, IBM Statistics Inc., USA. 
TABLE 1 Ingredient and chemical composition of the basal diets

\begin{tabular}{|c|c|c|}
\hline Ingredients & vo & Mo \\
\hline Corn Gluten meal (CP 60; Inzo, France) & 180 & - \\
\hline Soybean meal (CP 48; Inzo, France) & 50 & - \\
\hline Soyprotein concentrate (Estrilvo; CP 70; Sopropêche, France) & 170 & - \\
\hline Extruded peas (Aquatex, Sotexpro, France) & 30 & - \\
\hline Rapeseed meal (Primor 00; SudOuestAlimants, France) & 40 & - \\
\hline Whole wheat & 31.8 & 245.6 \\
\hline Soylecithin (Louis François, France) & 20 & - \\
\hline L-Lysine (Eurolysine) & 13.4 & - \\
\hline Micro mineral premix ${ }^{\mathrm{b}}$ & 0.00 & 0.00 \\
\hline Vitamin premix $x^{c}$ & 10 & 10 \\
\hline Yttrium oxide (Sigma-Aldrich, USA) & 0.1 & 0.1 \\
\hline Fish oil (southern hemisphere, Sopropêche, France) & - & 118.6 \\
\hline Rapeseed Oil (Daudruy, France) & 66 & - \\
\hline Linseed Oil (Daudruy, France) & 66 & - \\
\hline Palm Oil (Daudruy, France) & 33 & - \\
\hline \multicolumn{3}{|l|}{ Analysed proximate composition } \\
\hline Dry matter (DM), g/kg & 949.4 & 948 \\
\hline Calcium & 8.0 & 11.3 \\
\hline $\mathrm{Ca} / \mathrm{P}$ ratio (no unit) & 0.9 & 0.9 \\
\hline Magnesium & 0.95 & 1.76 \\
\hline Potassium & 4.2 & 12.2 \\
\hline Sodium & 1.4 & 9.4 \\
\hline
\end{tabular}

${ }^{a}$ Attractant premix: glucosamine, $5 \mathrm{~g}$; taurine, $3 \mathrm{~g}$; betaine, $3 \mathrm{~g}$; glycine, $2 \mathrm{~g}$ and alanine, $2 \mathrm{~g}$.

${ }^{b}$ Micro mineral premix (g/kg premix): $\mathrm{FeSO}_{4} \cdot 7 \mathrm{H}_{2} \mathrm{O}\left(21 \% \mathrm{Fe} ; 11.5 \% \mathrm{~S}\right.$; Merck 103965; Fontenay-sous-Bois, France), $25 \mathrm{~g} ; \mathrm{CuSO}_{4} \cdot 5 \mathrm{H}_{2} \mathrm{O}(25.45 \% \mathrm{Cu} ; 12.8 \%$ S; Sigma C8027, Saint-Quentin-Fallavier, France), $3 \mathrm{~g} ; \mathrm{MnSO}_{4} \cdot \mathrm{H}_{2} \mathrm{O}$ (33\% Mn; 19\% S; VWR Chemicals 25303.233; Fontenay-sous-Bois, France), 3 g; $\mathrm{ZnSO}_{4} \cdot 7 \mathrm{H}_{2} \mathrm{O}$ (36\% Zn; 18\% S; VWR Chemicals 29253.236; Fontenay-sous-Bois, France), 4 g; KI (76\% I; 24\% K; Sigma P4286, Saint-Quentin-Fallavier, France), 0.04 g; $\mathrm{Na}_{2} \mathrm{SeO}_{3}$ (46\% Se; 27\% Na; Sigma 71950, Saint-Quentin-Fallavier, France.), $0.03 \mathrm{~g}$; $\alpha$-cellulose (carrier) $964.93 \mathrm{~g}$.

'Vitamin premix (IU or mg/kg diet): DL-a tocopherol acetate, $60 \mathrm{IU}$; sodium menadione bisulphate, mg; retinyl acetate, 15,000 IU; DL-cholecalciferol, 3,000 IU; thiamin, $15 \mathrm{mg}$; riboflavin, $30 \mathrm{mg}$; pyridoxine, $15 \mathrm{mg}$; B12, $0.05 \mathrm{mg}$; nicotinic acid, $175 \mathrm{mg}$; folic acid, $500 \mathrm{mg}$; inositol, 1,000 mg; biotin, $2.5 \mathrm{mg}$; calcium pantothenate, $50 \mathrm{mg}$; choline chloride, 2,000 mg (UPAE, INRA).

\section{3 | RESULTS}

\section{1 | Feed intake and growth performance}

Data on feed intake (FI), weight gain (WG) and other indices of growth performance such as feed efficiency (FE) and daily growth index (DGI) are provided in Table 3. During the 12-week feeding trial, fish gained more than sixfold their initial weight. Fish fed $M$ diets had significantly higher feed intake, weight gain and feed efficiencies compared with $\mathrm{V}$ diet fed fish. Inclusion of the micromineral premix did not have an impact on the growth of the fish, irrespective of the type of basal diet. However, among the five groups fed the $\mathrm{V}$ diet, a tendency for higher weight gain was observed in the fish fed with the V60 diet. 


\begin{tabular}{|lrrrrrrr} 
Diet code & \multicolumn{1}{c}{ V0 } & \multicolumn{1}{c}{ V30 } & \multicolumn{1}{c}{ V60 } & V100 & V150 & \multicolumn{1}{c}{ M0 } & M100 \\
\hline Iron & 153.8 & 169.1 & 185.2 & 205.4 & 234.8 & 161.6 & 212.9 \\
Copper & 7.0 & 8.8 & 10.0 & 12.9 & 14.2 & 6.9 & 14.0 \\
\hline Manganese & 88.6 & 92.2 & 94.1 & 100.9 & 102.1 & 9.4 & 22.7 \\
Zinc & 42.9 & 44.1 & 46.8 & 52.5 & 58.1 & 62.8 & 72.5 \\
\hline Selenium & 0.24 & 0.28 & 0.33 & 0.40 & 0.54 & 1.09 & 1.27 \\
\hline
\end{tabular}

TABLE 2 Analysed dietary concentration of microminerals (mg/kg DM)

V0, Basal plant ingredient-based diet; M0, Basal fishmeal-based diet; V30, V60, V100 and V150, plant ingredient-based diets with 3, 6, 10 and $15 \mathrm{~g} / \mathrm{kg}$ inclusion of micromineral premix; M100, Fishmealbased diet with $10 \mathrm{~g} / \mathrm{kg}$ inclusion of micromineral premix.

TAB LE 3 Growth performance of rainbow trout fed the experimental diets for 12 weeks

\begin{tabular}{|c|c|c|c|c|c|c|}
\hline & IBW (g/fish) & FBW (g/fish) & Feed intake (g/fish) & Weight gain (g/fish) & FE & DGI \\
\hline V30 & $19.8 \pm 0.5$ & $145.8 \pm 4.5^{\mathrm{a}}$ & $116.9 \pm 1.3^{\mathrm{a}}$ & $126 \pm 4.8^{a}$ & $1.1 \pm 0.02^{\mathrm{a}}$ & $3 \pm 0.08^{a}$ \\
\hline V100 & $19.7 \pm 0.5$ & $145.3 \pm 5.7^{\mathrm{a}}$ & $115.9 \pm 3.5^{\mathrm{a}}$ & $125.5 \pm 5.4^{a}$ & $1.1 \pm 0.03^{a}$ & $3 \pm 0.07^{a}$ \\
\hline V150 & $20 \pm 0.3$ & $146.8 \pm 4.5^{\mathrm{a}}$ & $120.4 \pm 4.5^{\mathrm{ab}}$ & $126.8 \pm 4.8^{\mathrm{a}}$ & $1.1 \pm 0.07^{\mathrm{a}}$ & $3.1 \pm 0.1^{\mathrm{ab}}$ \\
\hline M100 & $19.7 \pm 0.5$ & $190.8 \pm 5.5^{b}$ & $131.2 \pm 2.4^{b}$ & $171.1 \pm 4.1^{b}$ & $1.4 \pm 0.03^{b}$ & $3.6 \pm 0.04^{c}$ \\
\hline$p$-value & .52 & .01 & .03 & .01 & .02 & .02 \\
\hline
\end{tabular}

V0, Basal plant ingredient-based diet; M0, basal fishmeal-based diet; V30, V60, V100 and V150, plant ingredient-based diets with 3, 6, 10 and 15 g/kg inclusion of micromineral premix; M100, fishmeal-based diet with $10 \mathrm{~g} / \mathrm{kg}$ inclusion of micromineral premix; IBW, Initial body weight; FBW, final body weight; FE, feed efficiency; DGI, daily growth index. DGI = 100*(FBW $\left.{ }^{1 / 3}-\mathrm{IBW}^{1 / 3}\right) /$ duration (84 days); FE = wet weight gain (g)/dry feed intake (g). Values within the same column with different superscript are statistically significant.

TABLE 4 Apparent availability (\%) of minerals in experimental diets fed to rainbow trout

\begin{tabular}{|c|c|c|c|c|c|c|c|c|c|}
\hline & $P$ & Mg & $\mathrm{Ca}$ & $\mathrm{K}$ & $\mathrm{Fe}$ & $\mathrm{Cu}$ & $\mathrm{Mn}$ & $\mathrm{Zn}$ & $\mathrm{Se}$ \\
\hline V30 & $60.8 \pm 0.8^{a}$ & $69.4 \pm 4.5^{\mathrm{b}}$ & $8.4 \pm 0.9$ & $88.9 \pm 0.6^{a}$ & $12.9 \pm 0.1^{d}$ & $35.9 \pm 3.1^{c}$ & $8.7 \pm 1^{a}$ & $38.6 \pm 2.2^{\mathrm{ba}}$ & $80.7 \pm 1.8^{b}$ \\
\hline V100 & $59.6 \pm 5.9^{a}$ & $70 \pm 3.9^{b}$ & $11.8 \pm 1.9$ & $89.2 \pm 0.4^{a}$ & $10.1 \pm 1.2^{b c}$ & $28.3 \pm 4.4^{b}$ & $10 \pm 2.6^{a}$ & $39.4 \pm 2^{\text {ba }}$ & $79.8 \pm 1.7^{b}$ \\
\hline V150 & $58.7 \pm 2.3^{\mathrm{a}}$ & $68.1 \pm 4.9^{b}$ & $7.9 \pm 5.6$ & $88.7 \pm 0.4^{a}$ & $7.5 \pm 0.5^{b}$ & $19.1 \pm 2.3^{\mathrm{a}}$ & $6.6 \pm 2.1^{a}$ & $34.5 \pm 1.8^{\mathrm{a}}$ & $80.8 \pm 2.1^{b}$ \\
\hline M100 & $67.5 \pm 1.2^{\mathrm{ab}}$ & $58.5 \pm 3.8^{\mathrm{a}}$ & $8.3 \pm 0.1$ & $97.1 \pm 0.1^{b}$ & $3.7 \pm 0.9^{a}$ & $35.1 \pm 3.7^{d}$ & $25.7 \pm 6.8^{b}$ & $45.8 \pm 3^{b}$ & $74.4 \pm 1.5^{a}$ \\
\hline$p$-value & .051 & .069 & .707 & .000 & .000 & .000 & .000 & .000 & .004 \\
\hline
\end{tabular}

V0, Basal plant ingredient-based diet; M0, Basal fishmeal-based diet; V30, V60, V100 and V150, plant ingredient-based diets with 3, 6, 10 and 15 g/kg inclusion of micromineral premix; M100, Fishmeal-based diet with $10 \mathrm{~g} / \mathrm{kg}$ inclusion of micromineral premix. Data presented as mean \pm SD; values within the same column having different superscripts are statistically different.

\section{2 | Apparent availability of minerals}

Data on apparent availability coefficient (AAC, \%) of minerals in the experimental diets to rainbow trout are presented in Table 4. The AAC of all the analysed macro-minerals and microminerals were higher in fish fed the $M$ diet. Supplementation of micromineral premix to the MO diet resulted in reduction of $A A C$ of the microminerals, most prominent for Fe. Among the $\mathrm{V}$ diet fed fish, the AAC of microminerals such as $\mathrm{Fe}, \mathrm{Cu}$ and $\mathrm{Zn}$ decreased with increasing level of premix and attained the lowest with V150 fed group. Premix supplementation to basal $\mathrm{V}$ diet did not have an impact on the AAC of $\mathrm{Mn}$, Se and also on the $\mathrm{AAC}$ of the macro-minerals such as $\mathrm{P}, \mathrm{Ca}, \mathrm{Mg}$ and $\mathrm{K}$, for which the dietary levels were kept constant.

\section{3 | Contribution of basal diet in meeting available micromineral requirements}

A comparison between the NRC recommendations (2011) and the contribution of available micromineral supply from the basal $\mathrm{V} O$ and $\mathrm{MO}$ diet to the requirements of corresponding microminerals for rainbow trout are presented in Table 5. In reference to NRC (2011) recommendations for rainbow trout, the Vo basal diet covered $34.3 \%$, 
$92.9 \%, 53.9 \%, 115 \%$ and $130.2 \%$ and the $\mathrm{MO}$ diet for $105.5 \%, 173.3 \%$, $24.2 \%, 234.7 \%$ and $580 \%$ of the minimal dietary inclusion levels of Fe, $\mathrm{Cu}, \mathrm{Mn}, \mathrm{Zn}$ and Se, respectively.

\subsection{Chemical composition of fish}

The major chemical composition of the body such as moisture (674 $\pm 5 \mathrm{~g} / \mathrm{kg})$, crude protein (155 $\pm 2 \mathrm{~g} / \mathrm{kg})$, crude fat $(166 \pm 6 \mathrm{~g} / \mathrm{kg})$, ash $(17 \pm 1 \mathrm{~g} / \mathrm{kg})$ and energy $(9.2 \pm 0.2 \mathrm{~kJ} / \mathrm{g})$ were not different between the treatments (data not shown). The initial and final mineral concentrations of fish fed experimental diets are presented in Table 6. Micromineral premix supplementation did not affect the concentration of macro-minerals such as $\mathrm{P}, \mathrm{Ca}, \mathrm{Mg}, \mathrm{K}$ and $\mathrm{Na}$. The final body concentration of $\mathrm{Cu}(p<.05), \mathrm{Zn}(p<.01)$ and Se $(p<.01)$ increased with premix inclusion level, while Fe and $\mathrm{Mn}$ were not significantly different between the $\mathrm{V}$ diet fed groups. In comparison with $\mathrm{M}$ diet fed groups, it was found that $\mathrm{Zn}$ and Se levels even in the V150 diet were insufficient to maintain the normal body mineral levels in rainbow trout.

\section{4 | DISCUSSION}

Excessive use of inorganic minerals in practical diets can be avoided by utilizing the intrinsic potential of minerals in feed ingredients (Sugiura et al., 1998). Tacon and De Silva (1983) documented exceedingly high concentrations above recommended levels and twofold to 11-fold variations for microminerals such as Fe (80-540 mg/kg), Cu (5-40 mg/ $\mathrm{kg}), \mathrm{Mn}(35-100 \mathrm{mg} / \mathrm{kg})$ and $\mathrm{Zn}(50-260 \mathrm{mg} / \mathrm{kg})$ within similar feed categories of commercial salmonid feeds that were available in Europe. Three decades down the line, the situation has not changed much, according to the recent report based on a survey on different Norwegian fish feeds over a decade from 2000 to 2010 (Sissener et al., 2013). The reported minimal and maximal dietary levels are as follows: Fe (65493 mg/kg); Cu (2.5-21 mg/kg); Mn (4.4-226 mg/kg); Zn (36-330 mg/ $\mathrm{kg})$; and Se (0.39-4.1 mg/kg). These data suggest that (i) high variations could be related to the differences in micromineral composition of the major feed ingredients; due to a diverse array of source and origin (ii), commercial fish feed formulations are more often negligent to the negative effects of excess micromineral supply. Given the diverse array of alternate feed ingredients of varying mineral concentrations, necessary strategies need to be devised to provide optimal levels, avoiding deficient or excess of microminerals in fish feeds.

The available micromineral levels from the basal diets (both $\mathrm{MO}$ and V0) fulfilled more than $90 \%$ of the respective micromineral requirements to rainbow trout except for Mn with reference to NRC (2011) recommendations. However, the final whole body concentrations indicated deviations from the earlier statement. Final body composition is a robust response to quantify macro-mineral requirement (Antony Jesu Prabhu, Schrama, \& Kaushik, 2013; Rodehutscord, 1996; Shearer, 1989) and can also be applied for microminerals (Shearer, 1995). Iron is the only essential micromineral for which the requirement is yet to be tested in rainbow trout (NRC, 2011). Shearer (1995) predicted an estimate of $21 \mathrm{mg} / \mathrm{kg}$ diet for normal Fe homoeostasis in $10 \mathrm{~g}$ rainbow trout. Dietary Fe requirement of Atlantic salmon is reported to be 60-100 mg/kg diet (Andersen, Maage, \& Julshamn, 1996; Naser, 2000), when fed $\mathrm{FeSO}_{4}$ supplemented casein-based diets. It can be assumed that total Fe supply of $154 \mathrm{mg} / \mathrm{kg}$ DM (from V0 diet) almost satisfied the minimal dietary Fe needs of rainbow trout. The AAC of Fe was constant at $13 \%$ until $\mathrm{V} 60$ and reduced significantly thereafter to $10 \%$ and $7.5 \%$ in V100 and V150, suggestive of an excess dietary supply only beyond V60. This is more likely because iron homoeostasis is primarily regulated at intestinal absorption stage by body iron stores and dietary Fe levels (Standal, Dehli, Rorvik, \& Andersen, 1999). Judging from the AAC and the higher but statistically non-significant values of whole body $\mathrm{Fe}$ in $\mathrm{V} 30$ and $\mathrm{V} 60$, it could be proposed that supplementation of $30 \mathrm{mg} \mathrm{Fe} / \mathrm{kg}$ (V60, $185 \mathrm{mg} \mathrm{Fe} / \mathrm{kg}$ ) would be required to the basal V0 diet.

The NRC (2011) recommended and the only available report on dietary $\mathrm{Cu}$ requirement of rainbow trout $(3 \mathrm{mg} / \mathrm{kg} \mathrm{DM})$ was based on growth and body Cu concentration, obtained by testing only two dietary

TAB LE 5 Comparison between the NRC (2011) recommendation on micromineral requirements to rainbow trout and available supply of microminerals from the basal $\mathrm{MO}$ and $\mathrm{VO}$ diets in the present study

\begin{tabular}{|c|c|c|c|c|c|c|}
\hline & \multirow{2}{*}{$\begin{array}{l}\text { Requirement of } \\
\text { rainbow trout } \\
\text { NRC (2011) }\end{array}$} & \multicolumn{2}{|c|}{$\begin{array}{l}\text { Available supply from } \\
\text { basal diet }(\mathrm{mg} / \mathrm{kg} \mathrm{DM})^{\mathrm{a}}\end{array}$} & \multirow{2}{*}{$\begin{array}{l}\text { Percentage contribution } \\
\text { of MO diet to NRC } \\
\text { (2011) recommendation }{ }^{\text {d }}\end{array}$} & \multirow{2}{*}{$\begin{array}{l}\text { Percentage contribution } \\
\text { of V0 diet to NRC (2011) } \\
\text { recommendation }^{d}\end{array}$} & \multirow{2}{*}{$\begin{array}{l}\text { Mineral balance from Vo } \\
\text { diet based on whole body } \\
\text { levels in this study }\end{array}$} \\
\hline & & M0-diet & Vo-diet & & & \\
\hline Copper & 3 & 5.2 & 2.79 & 173.3 & 92.9 & ++ \\
\hline Manganese & 12 & 2.9 & 6.47 & 24.2 & 53.9 & ++ \\
\hline Zinc & 15 & 35.2 & 17.25 & 234.7 & 115.0 & -- \\
\hline
\end{tabular}

NT, not tested in rainbow trout as per NRC (2011).

Available supply of microminerals from the basal diet was calculated as a product of the analysed dietary mineral concentration (mg/kg) and the AAC (\%). ${ }^{a}$ Calculated from data presented in Table 2 (dietary micro mineral concentration) and Table 4 (AAC of micro minerals) for MO and V0 diet.

${ }^{b}$ Indicates sufficiency of available supply from VO diet in maintaining whole body mineral balance.

${ }^{c} \mathrm{Fe}$ requirement provided within parenthesis is based on data from Shearer (1995).

${ }^{\mathrm{d}}$ Calculated as relative percentage of available supply from basal diet to the respective available requirement estimates. 


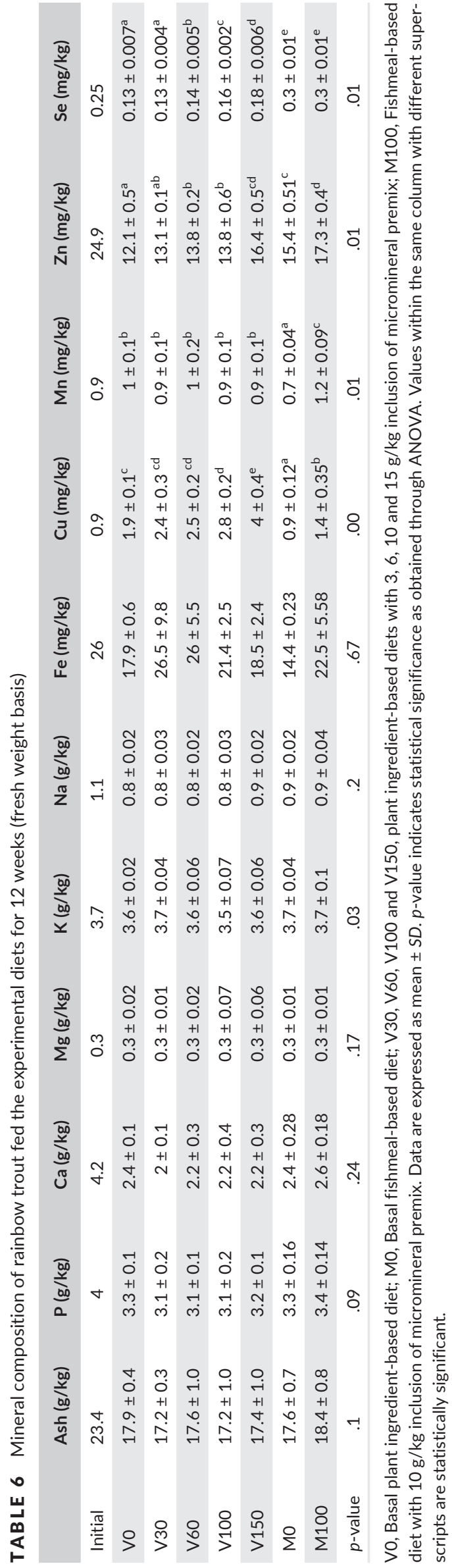

Cu levels (Ogino \& Yang, 1980). Reports on Cu requirement for several other fish species range from 3.1 to $12 \mathrm{mg} / \mathrm{kg}$ DM (Cao et al., 2014; Gatlin \& Wilson, 1986; Lin, Shie, \& Shiau, 2008; Lorentzen, Maage, \& Julshamn, 1998; Shao et al., 2010, 2012; Shiau \& Ning, 2003; Tan, Luo, Liu, \& Xie, 2011). In our study, the minimal dietary Cu concentration of $8.7 \mathrm{mg} / \mathrm{kg}$ DM (3.2 mg/kg DM on available basis) was sufficient to maintain normal body $\mathrm{Cu}$ concentration. The present estimate on available basis ( $3.2 \mathrm{mg} / \mathrm{kg} \mathrm{DM}$ ) was higher by $7 \%$ compared to the estimate of Ogino and Yang (1980) in rainbow trout, but actually this difference could be larger as the latter estimate of $3 \mathrm{mg} / \mathrm{kg} D M$ is on total basis. Although the diet used in the study of Ogino and Yang (1980) was based on purified ingredients, $100 \%$ availability may not be realistic, as assumed by NRC. Certain microminerals, especially $\mathrm{Cu}$, are very often reported to accumulate in the body when exposed to high dietary or aqueous supply (Kamunde, Grosell, Higgs, \& Wood, 2002). Even in the present study, it was observed that accumulation rate of $\mathrm{Cu}$ in the body increased steeply when dietary Cu was in excess of $13.2 \mathrm{mg} / \mathrm{kg} \mathrm{DM}$ (>4 mg/kg DM on available basis). This increase in whole body Cu was concurrent with the significant reduction in AAC of $\mathrm{Cu}$ in $\mathrm{V}$ fed fish possibly indicating a regulatory mechanism in response to the dietary $\mathrm{Cu}$ overload, as observed in Atlantic salmon (Berntssen, Lundebye, \& Maage, 1999). Moreover, despite the level of $\mathrm{Cu}$ in the $M$ and $V$ diets being comparable, the $\mathrm{V}$ diet fed fish had almost twice the level of whole body Cu compared to $\mathrm{M}$ fed fish, at both 0 and $100 \%$ premix inclusion levels. Our previous findings also show that fish fed $\mathrm{V}$ diets tend to accumulate more $\mathrm{Cu}$ in body (Antony Jesu Prabhu et al., 2015, 2016). In view of this, an optimal range of 8.7-13.2 mg/ $\mathrm{kg}$ DM total dietary $\mathrm{Cu}$ (3.2-4 $\mathrm{mg} / \mathrm{kg}$ DM on available basis) could be considered for rainbow trout fed the $\mathrm{V}$ diets to avoid excess accumulation of $\mathrm{Cu}$ in the body.

The $\mathrm{Mn}$ requirement of rainbow trout ranges from 12 to $13 \mathrm{mg} / \mathrm{kg}$ $\mathrm{DM}$ in purified diets on total basis, with growth and tissue $\mathrm{Mn}$ levels as response criteria (Ogino \& Yang, 1980). Similar to Cu, this estimate was obtained from testing only two dietary $\mathrm{Mn}$ levels. In the present study, fish fed the basal V0 diet with a total Mn content of $89 \mathrm{mg} / \mathrm{kg}$ $\mathrm{DM}(6.5 \mathrm{mg} / \mathrm{kg}$ DM on available basis) were able to maintain normal whole body $\mathrm{Mn}$ level, presumably due to the contribution from lupin meal. Lupin meal is reported to contain very high levels of $\mathrm{Mn}$, up to $1390 \mathrm{mg} / \mathrm{kg}$, as fed basis (NRC, 2011). Nevertheless, the estimate of $6.5 \mathrm{mg} / \mathrm{kg}$ on available basis, which was sufficient to maintain body $\mathrm{Mn}$ level in the present study, was lower by $46 \%$ than the estimate $(12 \mathrm{mg} /$ kg DM) recommended by NRC (2011) based on data from Ogino and Yang (1980). This could possibly be due to (i) over estimation of $\mathrm{Mn}$ requirement by Ogino and Yang (1980), as only two dietary levels were tested; (ii) present estimate is on available basis, while the earlier was on total basis as explained for $\mathrm{Cu}$; (iii) possibility of an underestimated $\mathrm{Mn}$ availability in the present study due to high total dietary Mn concentration in the basal VO diet and biliary excretion of absorbed $\mathrm{Mn}$ making a significant contribution to faecal Mn load (Sugiura et al., 1998). However, vertebral Mn concentration would have provided a more robust indicator to evaluate whether the Mn supplied by diet VO was sufficient to rainbow trout, as shown by Satoh, Takeuchi, and Watanabe (1991); in view of this, supplementation of $6-10 \mathrm{mg} / \mathrm{kg}$ inorganic $\mathrm{Mn}$ to the $\mathrm{V}$ diet may be beneficial. 
Zinc and selenium concentrations are naturally low in plant-derived ingredients as compared with fishmeal (Lall, 2002). Moreover, the availability of both Zn and Se can be reduced by phytic acid (Cheng \& Hardy, 2002) and inclusion of inorganic P or Ca salts (Antony Jesu Prabhu et al., 2014; Kousoulaki, Fjelldal, Aksnes, \& Albrektsen, 2010). Zinc is by far the most studied among the microminerals essential to fish, and rainbow trout in particular. NRC (2011) recommends the Zn requirement of rainbow trout as $15 \mathrm{mg} / \mathrm{kg}$ DM; while NRC (1993) recommended $30 \mathrm{mg} / \mathrm{kg}$ DM, both based on the range of $15-30 \mathrm{mg} / \mathrm{kg}$ DM reported for maximal growth and body $Z n$ levels when fed purified diets (Ogino \& Yang, 1978). In the present study, the whole body levels of $Z n$ in both $M$ and $\mathrm{V}$ diet fed fish were lower compared to the initial levels. Tri-calcium phosphate (TCP) at $7 \%$ (equivalent to levels present in fishmeal) resulted in complete unavailability of $\mathrm{Zn}$ to rainbow trout even with inclusion of $20 \mathrm{mg} / \mathrm{kg} \mathrm{ZnSO}_{4}$ (Satoh, Tabata, Izume, Takeuchi, \& Watanabe, 1987). Thereby, supplementation of $40 \mathrm{mg} / \mathrm{kg} \mathrm{Zn} \mathrm{(80} \mathrm{mg/kg} \mathrm{total} \mathrm{dietary} \mathrm{Zn)}$ was required to maintain whole body or vertebral $\mathrm{Zn}$ content when fed white fishmeal-based practical diets (Satoh, Takeuchi, \& Watanabe, 1987; Satoh, Tabata, et al., 1987). In diets containing 4\% TCP, dietary available $\mathrm{Zn}$ level of $15.7 \mathrm{mg} / \mathrm{kg}$ DM satisfied the growth and body Zn requirements of rainbow trout (Satoh, Tabata, et al., 1987). Thereby, $Z n$ supplementation higher than NRC (2011) recommendation is required in rainbow trout feeds to maintain normal $\mathrm{Zn}$ balance in the body, as suggested from the results of present study and Read et al. (2014).

As described earlier, the Se levels in plant ingredients are low compared to fishmeal. The basal V0 diet had a total Se concentration of $0.24 \mathrm{mg} / \mathrm{kg}$ DM which is about threefold to fourfold lower than observed with a fishmeal-based diet. NRC (2011) recommends a Se requirement of $0.15 \mathrm{mg} / \mathrm{kg} \mathrm{DM}$ based on weight gain as response criterion; while NRC (1993) had recommended $0.35 \mathrm{mg} / \mathrm{kg}$ DM which was based on maximal plasma GPx activity in rainbow trout reported by Hilton, Hodson, and Slinger (1980). Maximal weight gain at $0.2 \mathrm{mg}$ / $\mathrm{kg} \mathrm{DM}$ and Se accumulation in tissues beyond this level was reported in hybrid striped bass (Cotter, Craig, \& McLean, 2008). With increasing dietary Se levels, while a fixed proportion was defecated, excess Se was excreted by the kidneys (Hilton, Hodson, \& Slinger, 1982). Data on AAC and Se balance in the present study are in line with afore-mentioned study (Hilton et al., 1982) with a constant proportion (18\%-20\%) of ingested Se being eliminated through faeces and the non-faecal loss increasing from $30 \%$ in V0 fed fish to $50 \%$ in fish fed diet V150. Regarding the optimal inclusion level of dietary Se to fish, some of the recent reports advocate high levels of dietary Se (in mg/kg DM): 0.9-1.2 for hybrid striped bass (Jaramillo, Peng, \& Gatlin, 2009); 0.8 for cobia (Liu, Wang, Ai, Mai, \& Zhang, 2010); 1.18 for gibel carp (Han et al., 2011); 1.6 for largemouth bass (Zhu et al., 2012); 5.56 for yellowtail kingfish (Le \& Fotedar, 2013); and 1.6 for grouper (Lin, 2014) under normal health conditions. The findings of the present study suggested that dietary supply of $0.54 \mathrm{mg} / \mathrm{kg}$ DM (0.4 mg/kg DM on available basis) was not sufficient to maintain body Se balance. Fontagné-Dicharry et al. (2015) also reported similar results in whole body Se content of rainbow trout fry fed similar V-based diets and also on GPx activity. Therefore, higher inclusion of Se in plant ingredient-based diets is recommended to maintain normal Se balance and GPx levels in the body. Supranutritional levels of Se fortification in the form of Se-met or Se-yeast are reported to be beneficial in improving resistance to abiotic stress (Ribeiro et al., 2012; Rider et al., 2009; Saleh et al., 2014) and pathogen challenge (Le \& Fotedar, 2013, 2014), particularly in early life stages.

To conclude, the mineral levels in the Vo (basal) diet covered $98.1 \%, 92.9 \%, 53.9 \%, 115 \%$ and $130.2 \%$ of the minimal dietary inclusion levels of $\mathrm{Fe}, \mathrm{Cu}, \mathrm{Mn}, \mathrm{Zn}$ and Se to rainbow trout, respectively, with reference to NRC (2011) recommendations. However, data on whole body mineral contents showed that normal levels were maintained only for $\mathrm{Cu}$ and $\mathrm{Mn}$ through supply from basal VO diet. For $\mathrm{Zn}$ and Se, available supply even from the highest supplemented diet (V150) was not sufficient to maintain normal body mineral levels of rainbow trout in the present study. On the whole, optimal dietary inclusion levels of microminerals are altered while using fishmeal-free diets for rainbow trout.

\section{ACKNOWLEDGEMENTS}

The study was part of a PhD fellowship funded by INRA, under the INRA-WUR aquaculture platform; this work is also a contribution to the EU-funded project, ARRAINA: Advanced Research Initiatives for Nutrition \& Aquaculture (KBBE-2011-288925). The efforts of Fredric Terrier and other staff at the INRA experimental fish farm are acknowledged.

\section{REFERENCES}

Andersen, F., Maage, A., \& Julshamn, K. (1996). An estimation of dietary iron requirement of Atlantic salmon, Salmo salar L., parr. Aquaculture Nutrition, 2, 41-47.

Antony Jesu Prabhu, P., Geurden, I., Fontagné-Dicharry, S., Veron, V., Larroquet, L., Mariojouls, C., ... Kaushik, S. J. (2016). Responses in micro-mineral metabolism in rainbow trout to change in dietary ingredient composition and inclusion of a micro-mineral premix. PLoS One, 11, e0149378.

Antony Jesu Prabhu, P., Kaushik, S. J., Mariojouls, C., Surget, A., FontagnéDicharry, S., Schrama, J. W., \& Geurden, I. (2015). Comparison of endogenous loss and maintenance need for minerals in rainbow trout (Oncorhynchus mykiss) fed fishmeal or plant ingredient-based diets. Fish Physiology and Biochemistry, 41, 243-253.

Antony Jesu Prabhu, P., Schrama, J. W., \& Kaushik, S. J. (2013). Quantifying dietary phosphorus requirement of fish - A meta-analytic approach. Aquaculture Nutrition, 19, 233-249.

Antony Jesu Prabhu, P., Schrama, J. W., Mariojouls, C., Godin, S., FontagnéDicharry, S., Geurden, I., ... Kaushik, S. J. (2014). Post-prandial changes in plasma mineral levels in rainbow trout fed a complete plant ingredient based diet and the effect of supplemental di-calcium phosphate. Aquaculture, 430, 34-43.

Berntssen, M. H. G., Lundebye, A. K., \& Maage, A. (1999). Effects of elevated dietary copper concentrations on growth, feed utilisation and nutritional status of Atlantic salmon (Salmo salar L.) fry. Aquaculture, 174, 167-181.

Cao, J., Miao, X., Xu, W., Li, J., Zhang, W., \& Mai, K. (2014). Dietary copper requirements of juvenile large yellow croaker Larimichthys croceus. Aquaculture, 432, 346-350.

Cheng, Z. J., \& Hardy, R. W. (2002). Effect of microbial phytase on apparent nutrient digestibility of barley, canola meal, wheat and wheat middlings, measured in vivo using rainbow trout (Oncorhynchus mykiss). Aquaculture Nutrition, 8, 271-277. 
Cotter, P. A., Craig, S. R., \& McLean, E. (2008). Hyperaccumulation of selenium in hybrid striped bass: A functional food for aquaculture? Aquaculture Nutrition, 14, 215-222.

Fontagné-Dicharry, S., Godin, S., Liu, H., Antony Jesu Prabhu, P., Bouyssière, B., Bueno, M., ... Kaushik, S. J. (2015). Influence of the forms and levels of dietary selenium on antioxidant status and oxidative stress-related parameters in rainbow trout (Oncorhynchus mykiss) fry British Journal of Nutrition, 113, 1876-1887.

Gatlin, D. M., \& Wilson, R. P. (1986). Dietary copper requirement of fingerling channel catfish. Aquaculture, 54, 277-285.

Han, D., Xie, S., Liu, M., Xiao, X., Liu, H., Zhu, X., \& Yang, Y. (2011). The effects of dietary selenium on growth performances, oxidative stress and tissue selenium concentration of gibel carp (Carassius auratus gibelio). Aquaculture Nutrition, 741-749.

Hilton, J. W. (1989). The interaction of vitamins, minerals and diet composition in the diet of fish. Aquaculture, 79, 223-244.

Hilton, J. W., Hodson, P. V., \& Slinger, S. J. (1980). The requirement and toxicity of selenium in rainbow trout (Salmo gairdneri). The Journal of Nutrition, 110, 2527-2535.

Hilton, J. W., Hodson, P. V., \& Slinger, S. J. (1982). Absorption, distribution, half-life and possible routes of elimination of dietary selenium in juvenile rainbow trout (Salmo gairdneri). Comparative Biochemistry and Physiology Part C: Comparative Pharmacology, 71, 49-55.

Jaramillo, F. Jr, Peng, L. I., \& Gatlin, D. M. III (2009). Selenium nutrition of hybrid striped bass (Morone chrysops $\times$ M. saxatilis) bioavailability, toxicity and interaction with vitamin E. Aquaculture Nutrition, 15, 160-165.

Julshamn, K., Haugsnes, J., \& Utne, F. (1978). The contents of 14 major and minor elements (minerals) in Norwegian fish species and fish byproducts, determined by atomic absorption spectrophotometry. Fiskeridirektoratets Skrifter Serie Ernaering, 1, 117-135.

Kamunde, C., Grosell, M., Higgs, D., \& Wood, C. M. (2002). Copper metabolism in actively growing rainbow trout (Oncorhynchus mykiss): Interactions between dietary and waterborne copper uptake. Journal of Experimental Biology, 205, 279.

Kousoulaki, K., Fjelldal, P. G., Aksnes, A., \& Albrektsen, S. (2010). Growth and tissue mineralisation of Atlantic cod (Gadus Morhua) fed soluble P and Ca salts in the diet. Aquaculture, 309, 181-192.

Lall, S. P. (2002). The minerals. In R. H. Hardy \& J. E. Halver (Eds.), Fish nutrition (3rd ed., pp. 259-308). San Diego, CA: Academic Press, Elsevier Science.

Lall, S. P., (2008) Trace mineral requirements of fish and crustaceans. In P. Schlegel , S. Durosay, \& A. W. Jongbloed (Eds.), Trace elements in animal production systems (pp. 203-214). Wageningen: Academic Press.

Le, K. T., \& Fotedar, R. (2013). Dietary selenium requirement of yellowtail kingfish (Seriola lalandi). Agricultural Sciences, 4, 68-75.

Le, K. T., \& Fotedar, R. (2014). Immune responses to Vibrio anguillarum in yellowtail kingfish, Seriola lalandi, fed selenium supplementation. Journal of the World Aquaculture Society, 45, 138-148.

Lin, Y.-H. (2014). Effects of dietary organic and inorganic selenium on the growth, selenium concentration and meat quality of juvenile grouper Epinephelus malabaricus. Aquaculture, 430, 114-119.

Lin, Y.-H., Shie, Y.-Y., \& Shiau, S.-Y. (2008). Dietary copper requirements of juvenile grouper, Epinephelus malabaricus. Aquaculture, 274, 161-165.

Liu, K., Wang, X. J., Ai, Q., Mai, K., \& Zhang, W. (2010). Dietary selenium requirement for juvenile cobia, Rachycentron canadum L. Aquaculture Research, 41, e594-e601.

Lorentzen, M., Maage, A., \& Julshamn, K. (1998). Supplementing copper to a fish meal based diet fed to Atlantic salmon parr affects liver copper and selenium concentrations. Aquaculture Nutrition, 4, 67.

Naser, N. (2000). Role of iron in Atlantic salmon (Salmo salar) nutrition: Requirement, bioavailability, disease resistance and immune response (Vol. Ph.D, pp. 282). Halifax, Nova Scotia: Dalhousie University

NRC (1993) Nutrient requirements of fish. Washington, DC: National Research Council, The National Academies Press.
NRC (2011). Nutrient requirements of fish and shrimp. Washington, DC: National Research Council, The National Academies Press.

Ogino, O., \& Yang, G. Y. (1978). Requirement of rainbow trout for dietary zinc Bulletin of the Japanese Society of Scientific Fisheries, 44, 1015-1018.

Ogino, C., \& Yang, G. (1980). Requirements of carp and rainbow trout for dietary manganese and copper. Bulletin of the Japanese Society of Scientific Fisheries, 46, 455-458.

Read, E. S., Barrows, F. T., Gibson Gaylord, T., Paterson, J., Petersen, M. K., \& Sealey, W. M. (2014). Investigation of the effects of dietary protein source on copper and zinc bioavailability in fishmeal and plant-based diets for rainbow trout. Aquaculture, 432, 97-105.

Ribeiro, A. R. A., Ribeiro, L., SÆLEe, Ø., Hamre, K., Dinis, M. T., \& Moren, M. (2012). Selenium supplementation changes glutathione peroxidase activity and thyroid hormone production in Senegalese sole (Solea senegalensis) larvae. Aquaculture Nutrition, 18, 559-567.

Rider, S. A., Davies, S. J., Jha, A. N., Fisher, A. A., Knight, J., \& Sweetman, J. W. (2009). Supra-nutritional dietary intake of selenite and selenium yeast in normal and stressed rainbow trout (Oncorhynchus mykiss): Implications on selenium status and health responses. Aquaculture, 295, 282-291.

Rodehutscord, M. (1996). Response of rainbow trout (Oncorhynchus mykiss) growing from 50 to $200 \mathrm{~g}$ to supplements of dibasic sodium phosphate in a semipurified diet. Journal of Nutrition, 126, 324-331.

Saleh, R., Betancor, M. B., Roo, J., Montero, D., Zamorano, M. J., \& Izquierdo, M. (2014). Selenium levels in early weaning diets for gilthead seabream larvae. Aquaculture, 426-427, 256-263.

Satoh, S., Tabata, K., Izume, K., Takeuchi, T., \& Watanabe, T. (1987). Effect of dietary tricalcium phosphate on availability of zinc to rainbow trout. Nippon Suisan Gakkaishi, 53, 1199-1205.

Satoh, S., Takeuchi, T., \& Watanabe, T. (1987). Availability to rainbow trout of zinc in white fish meal and of various zinc compounds. Nippon Suisan Gakkaishi, 53, 595-599.

Satoh, S., Takeuchi, T., \& Watanabe, T. (1991). Availability of manganese and magnesium contained in white fish meal to rainbow trout Oncorhynchus mykiss. Nippon Suisan Gakkaishi, 57, 99-104.

Shao, X.-P., Liu, W.-B., Lu, K.-L., Xu, W.-N., Zhang, W.-W., Wang, Y., \& Zhu, J. (2012). Effects of tribasic copper chloride on growth, copper status, antioxidant activities, immune responses and intestinal microflora of blunt snout bream (Megalobrama amblycephala) fed practical diets. Aquaculture, 338-341, 154-159.

Shao, X., Liu, W., Xu, W., Lu, K., Xia, W., \& Jiang, Y. (2010). Effects of dietary copper sources and levels on performance, copper status, plasma antioxidant activities and relative copper bioavailability in Carassius auratus gibelio. Aquaculture, 308, 60-65.

Shearer, K. D. (1989). Whole body magnesium concentration as an indicator of magnesium status in rainbow trout (Salmo gairdneri). Aquaculture, 77, 201-210.

Shearer, K. D. (1995). The use of factorial modeling to determine the dietary requirements for essential elements in fishes. Aquaculture, 133, 57-72.

Shiau, S., \& Ning, Y. (2003). Estimation of dietary copper requirements of juvenile tilapia, Oreochromis niloticus $\times 0$. aureus. Animal Science, 77, 287-292.

Sissener, N. H., Julshamn, K., Espe, M., Lunestad, B. T., Hemre, G. I., Waagbø, R., \& Måge, A. (2013). Surveillance of selected nutrients, additives and undesirables in commercial Norwegian fish feeds in the years 2000-2010. Aquaculture Nutrition, 19, 555-572.

Standal, H., Dehli, A., Rorvik, K. A., \& Andersen, O. (1999). Iron status and dietary levels of iron affect the bioavailability of haem and nonhaem iron in Atlantic salmon Salmo salar. Aquaculture Nutrition, 5, 193-198.

Sugiura, S. H., Dong, F. M., \& Hardy, R. W. (2000). Primary responses of rainbow trout to dietary phosphorus concentrations. Aquaculture Nutrition, 6, 235-245.

Sugiura, S. H., Dong, F. M., Rathbone, C. K., \& Hardy, R. W. (1998). Apparent protein digestibility and mineral availabilities in various feed ingredients for salmonid feeds. Aquaculture, 159, 177-202. 
Tacon, A., \& De Silva, S. (1983). Mineral composition of some commercial fish feeds available in Europe. Aquaculture, 31, 11-20.

Tacon, A. G. J., \& Metian, M. (2008). Global overview on the use of fish meal and fish oil in industrially compounded aquafeeds: Trends and future prospects. Aquaculture, 285, 146-158.

Tan, X. Y., Luo, Z., Liu, X., \& Xie, C. X. (2011). Dietary copper requirement of juvenile yellow catfish Pelteobagrus fulvidraco. Aquaculture Nutrition, 17, 170-176.

Watanabe, T., Kiron, V., \& Satoh, S. (1997). Trace minerals in fish nutrition. Aquaculture, 151, 185-207.

Zhu, Y., Chen, Y., Liu, Y., Yang, H., Liang, G., \& Tian, L. (2012) Effect of dietary selenium level on growth performance, body composition and hepatic glutathione peroxidase activities of largemouth bass Micropterus salmoide. Aquaculture Research, 43, 1660-1668.

How to cite this article: Antony Jesu Prabhu P, Schrama JW, Fontagné-Dicharry $\mathrm{S}$, et al. Evaluating dietary supply of microminerals as a premix in a complete plant ingredient-based diet to juvenile rainbow trout (Oncorhynchus mykiss). Aquacult Nutr. 2018;24:539-547. https://doi.org/10.1111/anu.12586 